Case report

\title{
Simultaneous laparoscopic cholecystectomy and removal of an intrauterine device translocated to the right subdiaphragmal region: a case report
} Salih Krasniqi ${ }^{1}$, Elvis Ahmeti ${ }^{1}$, Sejdullah A Hoxha ${ }^{2}$, Halit Ymeri $^{2}$,
Ismet Shaqiri $^{1}$, Nexhmije B Kastrati-Spahija
and Avdyl S Krasniqi ${ }^{1 *}$

Addresses: ${ }^{1}$ Department of Surgery, University Clinical Centre of Kosova, Rrethi Spitalit str. p.n., Prishtina, 10000, Republic of Kosovo ${ }^{2}$ Department of Radiology, University Clinical Centre of Kosova, Rrethi Spitalit str. p.n., Prishtina, 10000, Republic of Kosovo

${ }^{3}$ Department of Gynecology and Obstetrics, University Clinical Centre of Kosova, Rrethi Spitalit str. p.n., Prishtina, 10000, Republic of Kosovo Email: SK - drsalihkrasniqi@hotmail.com; EA - elvisahmedi@yahoo.com; SAH - sejdullahhoxha@hotmail.com; HY - h_ymeri@hotmail.com; IS - smetshaqiri@gmail.com; NBKS - nspahija@yahoo.com; ASK* - dr_krasniqi2001@yahoo.com

* Corresponding author

Received: 26 February 2009 Accepted: 3 August 2009 Published: 25 August 2009

Cases Journal 2009, 2:6198 doi: 10.4076/1757-1626-2-6198

This article is available from: http://casesjournal.com/casesjournal/article/view/6198

(c) 2009 Krasniqi et al.; licensee Cases Network Ltd.

This is an Open Access article distributed under the terms of the Creative Commons Attribution License (http://creativecommons.org/licenses/by/3.0), which permits unrestricted use, distribution, and reproduction in any medium, provided the original work is properly cited.

\begin{abstract}
Introduction: Intrauterine devices are often accompanied by various complications, of which the uterine perforation constitutes the most dangerous one.

Case presentation: We present a case of a $4 \mathrm{I}$-year-old woman complaining of right upper quadrant pain. She had an intrauterine device inserted 12 years earlier without regular follow-up. Abdominal plain X-ray revealed the intrauterine device trans-located into the right subdiaphragmal area. Abdominal ultrasound showed gallbladder stones without any other sonographic pathologic finding. Patient underwent simultaneous laparoscopic cholecystectomy and removal of the intrauterine device from the right subdiaphragmal area.

Conclusion: Laparoscopy is an appropriate method for removal of intrauterine device translocated to the right subdiaphragmatic region.
\end{abstract}

\section{Introduction}

The use of laparoscopy enables close inspection of inner organs. Among the advantages of the laparoscopy are its use in trauma setting, blunt and/or penetrating trauma, acute abdomen and peritonitis $[1,2]$. Use of intrauterine devices (IUD) has been found to be associated with several complications such as bleeding, perforation or migration into surrounding tissues or the omentum. For dislodged IUDs the removal is recommended because of the potential inflammatory responses that may cause obstruction or perforation [3]. Here we present a case of patient that had simultaneous laparoscopic removal of dislodged IUD and the gallbladder.

\section{Case presentation}

A 41-year-old Kosovan Albanian woman presented with right upper quadrant (RUQ) pain for six months. The past medical history revealed the insertion of an intra uterine 
device (IUD) 12 years ago without regular follow-up. A chest X-ray showed a radio opaque foreign body resembling IUD in the right subdiafragmal area (Figures 1 and 2). The abdominal ultrasound showed only presence of gallbladder stones. The biochemistry and hematology tests were within normal range. The patient was electively taken to the operating room. 4-port "Wolf" laparoscopic equipment was used to remove the translocated IUD (Figures 3 and 4) and the gallbladder as well. The patient was discharged after 24 hours in excellent condition.

\section{Discussion}

Since the first reported laparoscopy in 1901 - "ventroscopy" and until now the indications for this method of examination has been constantly increasing [1]. The first cases of removal of dislodged IUDs using the laparoscopy have been published in late 70's [4,5]. Dislodgement of the IUD is accompanied with different complications. One of the most frequent is unwanted pregnancy, whether intrauterine or ectopic [6-10].

As it has been already stated the dislodgment can bring the IUD in the surrounding organs or the omentum. There were reported cases of the dislodgment in small intestines, rectosigmoid colon, peritoneum, gallbladder, appendix, annexes, iliac vein as well as the omentum [3-20]. By carefully searching the literature published so far we found 44 reported cases of the IUD displaced in rectum and/or sigmoid. In eight of them, the removal of the displaced IUD was performed transrectally [8]. These cases emphasize the importance of the rectal and endoscopic examination in patients suspected or found to have dislodged IUD [6-13]. The most frequent anchorage of these dislodged devices was the omentum (45 cases) and

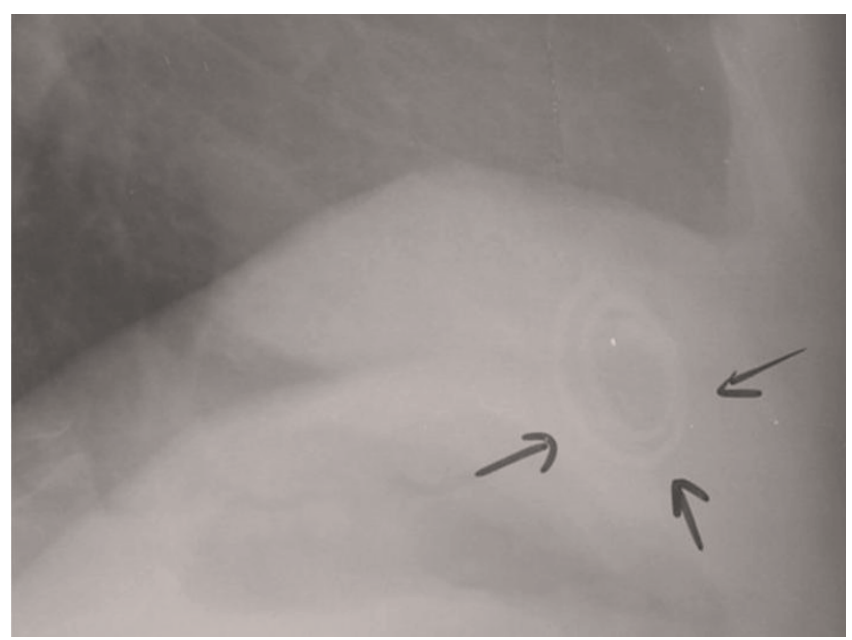

Figure I. Chest X-ray PA showing the radioopaque IUD in the right subdiaphragmal region.

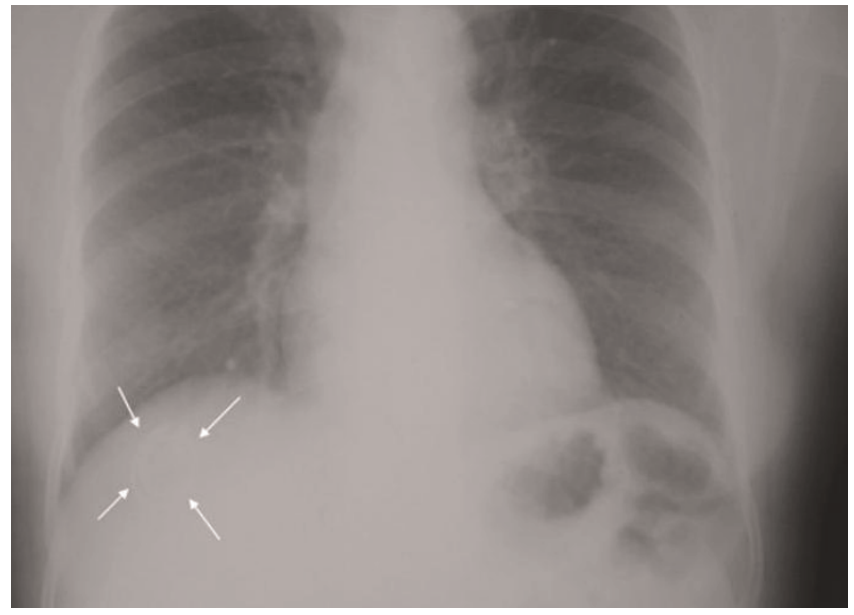

Figure 2. Chest $X$-ray LL showing the radioopaque IUD in the right subdiaphragmal region.

peritoneum (41 cases). There are reported cases of the localization in periappendicular area ( 9 cases) and in the small intestines (3 cases) $[9,14]$. In 24 reported cases the dislodgement of the IUD was in the urinary bladder and one of them was accompanied with stone formation in the bladder around the IUD $[9,15,16]$. To our knowledge, the case we present is the only reported IUD dislodgement in the upper abdomen, or more specifically in the right subdiaphragmal area.

Due to a potential inflammatory response and consequent obstruction and/or perforation, the majority of authors recommend the removal of the dislodged IUD laparoscopically. Laparotomy remains an option in cases were laparoscopy may not be successful $[17,20]$. Driven by these recommendations we decided to use laparoscopy for the removal of this dislodged foreign body, and at the

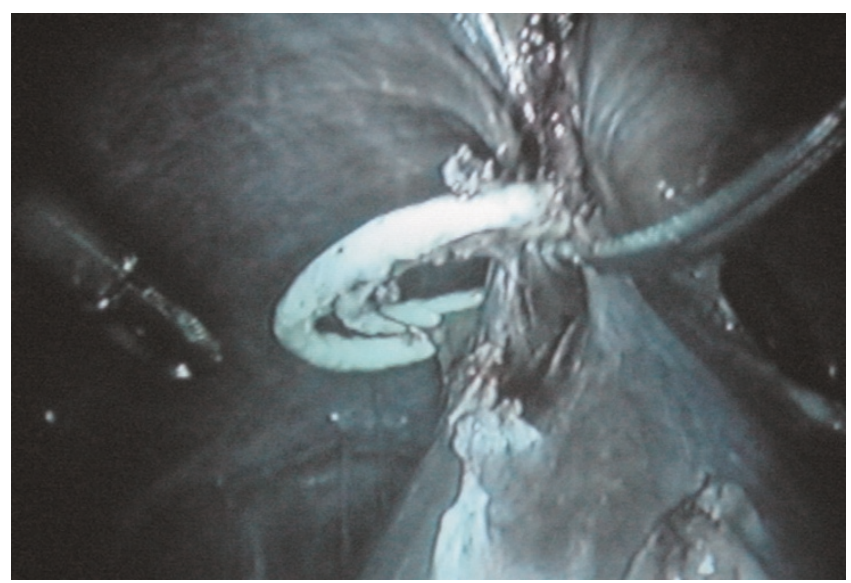

Figure 3. The IUD "in situ" during laparoscopy. 


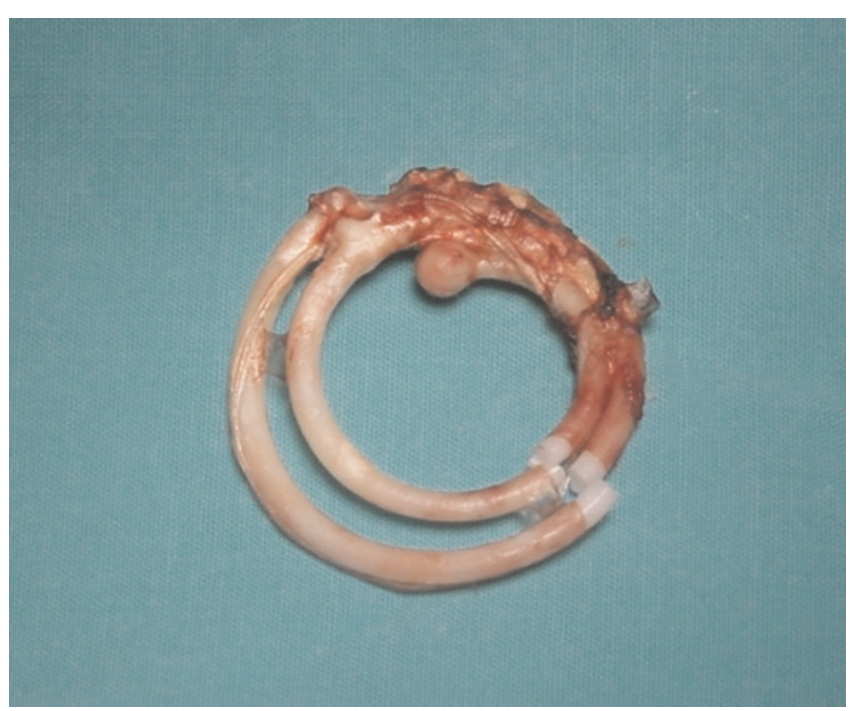

Figure 4. The IUD externalized.

same time perform the cholecystectomy. 24 hours later the patient was discharged from the hospital in excellent condition. To our awareness, this is the only reported case of the laparoscopic concurrent removal of a foreign body and cholecystectomy.

In conclusion, we have found the laparoscopy as a method of choice for the removal of the dislodged IUD because of the patients' comfort and minimal hospital stay.

\section{Abbreviations}

IUD, intrauterine device; RUQ, right upper quadrant.

\section{Consent}

Written informed consent was obtained from the patient for publication of this case report and accompanying images. A copy of the written consent is available for review by the journal's Editor-in-Chief.

\section{Competing interests}

The authors declare that there are no competing interests.

\section{Authors' contributions}

AK and EA designed the work; SK and IS performed the operation; SK and AK wrote the paper with contribution from EA and SH; the other authors contributed equally to this work.

\section{Reference}

I. Basil H, Irvin M: The History of Endoscopy: The American Perspective. In Gastroenterological Endoscopy. Volume I. Ist edition. Edited by Classen M, Tytgat G, Lightdale CH. New York: Thiemme Stutgart; 2002:2-16.

2. Frimberger E, Feussner H: Laparoscopic Investigation and Combined Laparocsopic and Endoscopic Procedures. In
Gastroenterological Endoscopy. Volume I. Ist edition. Edited by Classen M, Tytgat G, Lightdale CH. New York: Thiemme Stutgart; 2002:22I-240.

3. Barsaul M, Sharma N, Sangwan K: $\mathbf{3 2 4}$ cases of misplaced IUCD-a 5 year study. Trop Doct 2003, 33:II-12.

4. Acosta Bendek E: Removal from the abdominal cavity of an intrauterine device by culdoscopy. Rev Colomb Obstet Ginecol 1977, 28:85-88.

5. Valle RF, Sciarra JJ, Freeman DW: Hysterocsopic removal of intrauterine devices with missing filaments. Obstet Gynecol 1977, 49:55-60.

6. Miranda L, Settembre A, Capasso P, Cucurullo D, Pisaniello D, Corcione F: Laparoscopic removal of an intraperitoneal translocated intrauterine contraceptive device. Eur J Contracept Reprod Health Care 2003, 8: I22-I25.

7. Kwong FN, Rai H, Mayne C: Ectopic pregnancy with a translocated Mirena intrauterine system. I Fam Plann Reprod Health Care 2002, 28:95-96.

8. Banerjee N, Kriplani A, Roy KK, Bal S, Takkar D: Retrieval of lost Copper-T from the rectum. Eur J Obstet Gynecol Reprod Biol I998, 79:2II-2I2.

9. Kassab B, Audra P: The migrating intrauterine device. Case report and review of the literature. Contracept Fertil Sex 1999, 27:696-700.

10. Adoni A, Ben Chetrit A: The management of intrauterine devices following uterine perforation. Contraception 1991, 43:77-8I

II. Hogston P: Removal of an intra-uterine contraceptive device per rectum. J Obstet Gynaecol 1986, 7:75.

12. Juarez-Azpilcueta A, Romero-Hernandez S, Motta-Martinez E: Uterine and rectosigmoid perforation secondary to placement of an intrauterine device, case report with literature review. Gac Med Mex 2003, 139:73-75.

13. Beard RJ: Unusual presentation of translocated intrauterine contraceptive device. Lancet I98I, I:837.

14. Cullier F, Ben Ghalem S, Haffaf Y: Intrauterine device appendicitis: an exceptional complication. J Gynecol Obstet Biol Reprod 2003, 32:55-57.

15. Atakan H, Kaplan M, Erturk E: Intravesical migration of intrauterine device resulting in stone formation. Urology 2002, 60:9II.

16. Dabbas $M$, Maaita M: Ureteric calculus around an intrauterine contraceptive device. J Obstet Gynaecol 2002, 22:101-102.

17. Mittal S, Gupta I, Lata P, Mahajan U, Gupta AN: Management of translocated and incarcerated intrauterine contraceptive devices. Aust N Z J Obstet Gynaecol 1986, 26:232-234.

18. Gupta I, Sawhney H, Mahajan U: Laparocsopic removal of translocated intrauterine contraceptive devices. Aust $\mathrm{N} J \mathrm{~J}$ Obstet Gynaecol 1989, 29:352-355.

19. McKenna PJ, Mylotte MJ: Laparoscopic removal of translocated intrauterine contraceptive devices. Br J Obstet Gynaecol 1982, 89:163-165.

20. Mittal S, Kumar S, Roy KK: Role of endoscopy in retrieval of misplaced intrauterine device. Aust N Z J Obstet Gynaecol 1996, 36:49-5I. 